Rev. Fac. Agron. (LUZ). 2021, 38(4): 1087-1107. Octubre-Diciembre.

DOI: https://doi.org/10.47280/RevFacAgron(LUZ).v38.n4.19

ISSN 2477-9407

\title{
Willingness to pay and consumer preferences for organic lettuce (Lactuca sativa L. )
}

\section{Disposición a pagar y preferencias por lechugas orgánicas (Lactuca sativa L.) \\ Disposição a pagar e preferências por alface orgânica (Lactuca sativa L)}

\author{
Arcadio A. Cerda ${ }^{1}$, Leidy Y. García ${ }^{1 *}$, Angela I. Viscay ${ }^{2}$ and \\ Beatriz M. López ${ }^{2}$
}

\begin{abstract}
${ }^{1}$ Faculty of Economics \& Business, University of Talca, 1 Poniente 1141, Talca, Chile, Email: (AC) acerda@utalca.cl, (D) ; (LG) lgarcia@utalca.cl, (iD) ${ }^{2}$ Graduate of Commercial Engineer, University of Talca, Talca, Chile, Email: (AV) angela.viscay@gmail.com, (D); (BL) beatriz.m.lg17@gmail.com, (iD.
\end{abstract}

\section{Abstract}

Global production of organic products has grown significantly due to increased environmental awareness and healthier lifestyles. However, vegetable growers often lack relevant information about people's preferences and willingness to pay (WTP) for such products. This difficulty is even more pronounced in developing countries, as Chile, mainly due to the low demand increase for organic products. This research aims to analyze preferences and WTP for Chilean organic lettuce. To obtain the WTP, the contingent valuation (CV) method and conjoint analysis (CA) was applied. The data were obtained from a cross-sectional survey using a representative sample of 416 subjects from the Maule region, Chile, stratified by income level. The results showed that subjects were willing to pay a premium of $26.72 \%$ and $52.83 \%$ for an organic head of lettuce compared to conventionally grown products, according to CA and CV methods, respectively. These results show a strong preference for organic products. Furthermore, the CA method indicated that the organic variety of Lactuca sativa L. var. crispa L., at its lowest observed price, was the consumer's product of choice. Finally, the main reasons to consume this type of product are, firstly, its higher quality, followed by its taste or smell, and finally, it has better nutritional contents. Therefore, lettuce growers

Received el 27-08-2020 • Accepted el 23-02-2021.

*Corresponding author: Email: lgarcia@utalca.cl. 
Rev. Fac. Agron. (LUZ). 2021, 38(4):1088-1108. Octubre-Diciembre.

\section{Cerda et al.}

ISSN 2477-9407

can use the estimated premium price as a reference when making decisions about production and pricing.

Keywords: organic production; conjoint analysis; contingent valuation; lettuce; Chile.

\section{Resumen}

La producción mundial de productos orgánicos ha crecido significativamente debido a una mayor conciencia ambiental y a estilos de vida más saludables. Sin embargo, los productores de verduras a menudo carecen de información relevante acerca de las preferencias y disposición de las personas a pagar (WTP) por dichos productos. Esta dificultad, es aún más pronunciada en los países en desarrollo, como Chile, debido principalmente al bajo crecimiento de la demanda de productos orgánicos. Esta investigación tiene como objetivo analizar las preferencias y el WTP para la lechuga orgánica chilena. El método para obtener el WTP fue aplicar la valoración contingente (CV) y el análisis conjunto (CA). Los datos se obtuvieron de una encuesta transversal utilizando una muestra representativa de 416 sujetos dentro de la región del Maule de Chile, estratificados por nivel de ingresos. Los resultados muestran una disposición a pagar por un sobreprecio de $26,72 \%$ y 52,83 $\%$ por cabeza de lechuga orgánica en comparación con los productos cultivados convencionalmente, de acuerdo con los métodos $\mathrm{CA}$ y $\mathrm{CV}$, respectivamente, evidenciándose una fuerte preferencia por los productos orgánicos. Además, el método CA indicó que la variedad Lactuca sativa L. var. crispa L., del precio más bajo observado, fue el producto elegido por los consumidores. Finalmente, las principales razones para consumir este tipo de productos son, su mayor calidad, su sabor u olor, y finalmente, sus mejores contenidos nutricionales. Los productores de lechuga pueden utilizar el precio de la prima estimada como referencia al tomar decisiones sobre producción y precios.

Palabras clave: producción orgánica, análisis conjunto, valoración contingente, lechuga, Chile.

\section{Resumo}

A produção global de produtos orgânicos cresceu significativamente devido a uma maior consciência ambiental e estilos de vida mais saudáveis. No entanto, os produtores de vegetais geralmente carecem de informações relevantes sobre as preferências das pessoas e a disposição de pagar (WTP) por tais produtos. Essa dificuldade é ainda mais pronunciada em países em desenvolvimento, como o Chile, principalmente devido ao baixo crescimento da demanda por produtos orgânicos. Esta pesquisa tem como objetivo analisar as preferências e a WTP pela alface orgânica chilena. O método de obtenção da WTP consistia em aplicar a avaliação contingente (CV) e a análise conjunta (CA). Os dados foram obtidos a partir de uma pesquisa transversal usando uma amostra representativa de 416 indivíduos na região de Maule, no Chile, estratificada por nível de renda. 
Rev. Fac. Agron. (LUZ). 2021, 38(4):1088-1108. Octubre-Diciembre.

Cerda et al.

ISSN 2477-9407

Os resultados mostram uma disposição a pagar um prêmio de $26,72 \%$ e $52,83 \%$ por cabeça de alface orgânica em relação aos produtos de cultivo convencional, segundo os métodos CA e CV, respectivamente, apresentando forte preferência pelos produtos orgânicos. Além disso, o método $\mathrm{CA}$ indicou que a variedade Lactuca sativa L. var. crispa L., com o menor preço observado, foi o produto de escolha dos consumidores. Por fim, os principais motivos para consumir este tipo de produto são a sua qualidade superior, o seu sabor ou cheiro e, por último, o seu melhor conteúdo nutricional. Os produtores de alface podem usar o preço premium estimado como referência ao tomar decisões de produção e preço.

Palavras-chave: produção orgânica; análise conjunta; avaliação contingente; alface Chile.

\section{Introduction}

The demand for organic products has experienced considerable growth since the second half of the $1990 \mathrm{~s}$, and this trend is forecast to continue in the coming years. The growth of this market can be attributed to increased consumer health problems, greater awareness of the benefits of eating organically grown food and higher income levels (Ahmed et al., 2020; Britwum and Yiannaka, 2019; Wang et al., 2017).

The available data on the supply of organic food products indicate an upward trend over time both in certified organic food production and in the number of producers. Some studies show that organic agricultural land worldwide, including lands being converted for that use, amounted to around seventy -one million hectares in 2018, whereas North America and Latin America only had shares of $5 \%$ and $11 \%$, respectively, with a continuous increase in the last twenty years (Willer et al., 2020). However, during 2017-2018, countries like the United States and Chile reduced

\section{Introducción}

La demanda de productos orgánicos ha experimentado un crecimiento considerable desde la segunda mitad de la década de 1990 y se prevé que esta tendencia continúe en los próximos años. El crecimiento de este mercado se puede atribuir a un aumento de los problemas de salud de los consumidores, una mayor conciencia de los beneficios de comer alimentos cultivados orgánicamente y mayores niveles de ingresos (Ahmed et al., 2020; Britwum y Yiannaka, 2019; Wang et al., 2017).

Los datos disponibles sobre la oferta de productos alimenticios orgánicos indican una tendencia ascendente en el tiempo tanto en la producción de alimentos orgánicos certificados como en el número de productores. Algunos estudios muestran que las tierras agrícolas orgánicas en todo el mundo, incluidas las tierras que se están convirtiendo para ese uso, ascendieron a alrededor de setenta y un millones de hectáreas en 2018, mientras que América del Norte y América Latina solo tenían 
Rev. Fac. Agron. (LUZ). 2021, 38(4):1088-1108. Octubre-Diciembre.

\section{Cerda et al.}

their total organic hectares by $0,4 \%$ and 16,0 \%, respectively (Willer et $a l .$, 2020). Nevertheless, studies have shown that some companies have been reluctant to supply organic products due to higher associated production costs and the accreditation required to carry out such operations (Wang, Zhu and Chu, 2017). Still, given the increased demand for organic products, it is clear that citizens' environmental awareness is increasing, but it is not yet high enough to warrant sustained production of organic products and services in developing countries.

In Chile, the barriers to organic food consumption are related to the lack of information and availability (Kushwah et al., 2019). Part of the above factors has been spurred by consumers' per capita income levels, as the demand for organic products, as with normal goods, is expected to increase along with higher incomes (Ranjbarshamsi et al., 2016).

There is only limited information about consumer preferences and their willingness to pay (WTP) for organic products in developing countries, despite extensive research in more developed countries (Bhattarai, 2019; Li et al., 2019; Pham et al., 2019; Wang et al., 2017). The literature that measures WTP and certain attributes that are particularly related to avoiding contamination of fruits and vegetables are extensive, but it does not necessarily focus on organic agricultural products, much less on organic lettuce (Nishi, 2017).

$$
\text { Studies analyzing }
$$

the characteristics and WTP of Chilean organic products have been performed participaciones del $5 \%$ y el $11 \%$, respectivamente, con un aumento continuo en los últimos veinte años (Willer et al., 2020). Sin embargo, durante 2017-2018, países como Estados Unidos y Chile redujeron sus hectáreas orgánicas totales en $0,4 \%$ y $16,0 \%$, respectivamente (Willer et al., 2020). Sin embargo, los estudios han demostrado que algunas empresas se han mostrado reacias a suministrar productos orgánicos debido a los mayores costos de producción asociados y la acreditación requerida para llevar a cabo dichas operaciones (Wang, Zhu y Chu, 2017). Aún así, dada la creciente demanda de productos orgánicos, está claro que la conciencia ambiental de los ciudadanos está aumentando, pero aún no es lo suficientemente alta como para justificar la producción sostenida de productos y servicios orgánicos en los países en desarrollo.

En Chile, las barreras al consumo de alimentos orgánicos están relacionadas con la falta de información y disponibilidad (Kushwah et al., 2019). Parte de los factores anteriores ha sido estimulado por los niveles de ingreso per cápita de los consumidores, ya que se espera que la demanda de productos orgánicos, al igual que con los bienes normales, aumente junto con mayores ingresos (Ranjbarshamsi et al., 2016).

Existe información limitada sobre las preferencias de los consumidores y su disposición a pagar (WTP) por productos orgánicos en países en desarrollo, a pesar de una extensa investigación en países más desarrollados (Bhattarai, 2019; Li et 
Rev. Fac. Agron. (LUZ). 2021, 38(4):1088-1108. Octubre-Diciembre.

for grapes (Cerda et al., 2011), apples (Cerda et al., 2012), pears (Cerda et al., 2015). Methods used to estimate WTP include contingent valuation (CV) based on consumer demand theory and discrete choice experiments based on random utility theory or a conjoint analysis (CA) method based on consumer measurement theory (Ghimire et al., 2016).

The literature shows disparate results on preferences and WTP for organic products. For example, in several studies, sociodemographic data did not reflect a significant influence on WTP, or its effect varied considerably depending on the type of product considered. The same was observed with the WTP a premium for an organic product, as many studies have shown a large positive WTP; however, it also varied widely across product categories. In general, studies have shown that people are willing to pay $10 \%$ to $40 \%$ premiums for organic food. Furthermore, consumers displayed higher WTP within a hypothetical context using $\mathrm{CV}$ measurement than they were in a real context. (Bhattarai, 2019; Cerda et al., 2014; Pham et al., 2019).

Knowing consumer preferences and their WTP is quite relevant because these data allow local producers to improve their decisionmaking processes regarding production, distribution, and pricing strategies. This in turn enables them to successfully participate in the organic produce market, both to attract more consumers daily and to work with a greater number of suppliers (Schleenbecker and Hamm, al., 2019; Pham et al., 2019; Wang et al., 2017). La literatura que mide la WTP y ciertos atributos que están particularmente relacionados con evitar la contaminación de frutas $\mathrm{y}$ verduras es extensa, pero no necesariamente se enfoca en productos agrícolas orgánicos y mucho menos en lechugas orgánicas (Nishi, 2017).

Se han realizado estudios que analizan las características y WTP de los productos orgánicos chilenos para uvas (Cerda et al., 2011), manzanas (Cerda et al., 2012), peras (Cerda et al., 2015). Los métodos utilizados para estimar la WTP incluyen la valoración contingente (CV) basada en la teoría de la demanda del consumidor y experimentos de elección discreta basados en la teoría de la utilidad aleatoria o un método de análisis conjunto (CA) basado en la teoría de medición del consumidor (Ghimire et al., 2016).

La literatura muestra resultados dispares sobre las preferencias y la WTP de los productos orgánicos. Por ejemplo, en varios estudios, los datos sociodemográficos no reflejaron una influencia significativa en la WTP, o su efecto varió considerablemente según el tipo de producto considerado. Lo mismo se observó con la WTP una prima para un producto orgánico, ya que muchos estudios han demostrado una gran WTP positiva; sin embargo, también varió ampliamente entre las categorías de productos. En general, los estudios han demostrado que las personas están dispuestas a pagar entre el $10 \%$ y el $40 \%$ de primas por alimentos orgánicos. Además, los consumidores mostraron una DAP 
Rev. Fac. Agron. (LUZ). 2021, 38(4):1088-1108. Octubre-Diciembre.

\section{Cerda et al.}

2013). Moreover, WTP estimates provide useful information on how consumers value organic and other important characteristics in products.

This study focuses on the consumption of lettuce because it is considered a product of frequent use, and there is a high demand for them (FAO, 2020; Shatilov et al., 2019). In addition, given the changes in consumer tastes (Rahman et al., 2021), there is a significant potential market for organic lettuces, which would provide new production opportunities for vegetable farmers (Jouzi et al., 2017). The objective of this research is to analyze consumers' preferences and WTP for Chilean organic lettuce. The attribute of greatest importance to consumers of organic lettuce is identified and compared with the WTP for such products. The methods used were CA and CV. In the case of $\mathrm{CA}$, it were used ranking and rating approaches.

\section{Materials and methods}

The research was analytical with an ex-post-fact and transactional design, since the information was taken without manipulation of variables and in a single moment on time. The data were quantitative, and the unit of analysis corresponds to individuals from the Maule Region, Chile. Within this population, the groups of interest were women and men over 18 years of age that belonged to the mediumlow income (C3), medium-high income (C2), and high income (ABC1) groups. The sample selection method was non-probabilistic and the sample más alta en un contexto hipotético utilizando la medición de $\mathrm{CV}$ que en un contexto real. (Bhattarai, 2019; Cerda et al., 2014; Pham et al., 2019).

El conocimiento de las preferencias de los consumidores y su WTP es bastante relevante porque estos datos permiten a los productores locales mejorar sus procesos de toma de decisiones con respecto a las estrategias de producción, distribución y precios. Esto, a su vez, les permite participar con éxito en el mercado de productos orgánicos, tanto para atraer a más consumidores a diario como para trabajar con un mayor número de proveedores (Schleenbecker y Hamm, 2013). Además, las estimaciones de la WTP proporcionan información útil sobre cómo los consumidores valoran las características orgánicas y otras características importantes de los productos.

Este estudio se centra en el consumo de lechuga porque se considera un producto de uso frecuente y existe una alta demanda de las mismas (FAO, 2020; Shatilov et al., 2019). Además, dados los cambios en los gustos de los consumidores (Rahman et al., 2021), existe un mercado potencial significativo para las lechugas orgánicas, lo que brindaría nuevas oportunidades de producción para los productores de hortalizas (Jouzi et al., 2017). El objetivo de esta investigación es analizar las preferencias de los consumidores y la DAP de la lechuga orgánica chilena. Se identifica el atributo de mayor importancia para los consumidores de lechuga orgánica y se compara con la WTP de dichos productos. Los métodos utilizados 
Rev. Fac. Agron. (LUZ). 2021, 38(4):1088-1108. Octubre-Diciembre.

Cerda et al.

ISSN 2477-9407

size (416 subjects) was determined by convenience, considering the ease of administration, low costs, and the availability of demographic data.

\section{Survey description}

The survey was carried out during September and October 2018, in the most representative cities of the Maule region, Chile, such as Talca, Linares, and Curicó, with a total population of over 400,000 . The final survey was conducted in the form of personal interviews in people's homes. The Cronbach's alpha coefficient for the survey was 0.812 , which indicated that it was reliable.

The survey consisted of applying a questionnaire structured in four sections, which included closed ended, ranking, ordering, and Likert questions. The first section on attributes and preferences included a Likert scale of one to five, with statements related to the organic and conventional production methods of lettuce, the importance of price, production method, and preferences regarding variety and types.

The second section on contingent valuation included a hypothetical market which is proposed to the respondents, where the organic product offered, and its availability are described. Respondents are asked directly if they would be willing to pay for a unit of organic lettuce and a random price (bid) is offered among the 10 possible estimated values.

According to people's responses, a second question is asked for a price higher than the one proposed or a lower one, to apply the doublebounded dichotomous method. In the fueron CA y CV. En el caso de CA, se utilizaron enfoques de ordenamiento (ranking) y calificación (rating).

\section{Materiales y métodos}

La investigación fue analítica con un diseño ex-post-facto y transeccional, ya que la información fue tomada sin manipulación de variables y en un solo momento en el tiempo. Los datos fueron cuantitativos y la unidad de análisis corresponde a individuos de la Región del Maule, Chile. Dentro de esta población, los grupos de interés fueron mujeres y hombres mayores de 18 años pertenecientes a los grupos de ingreso medio-bajo (C3), ingreso medio-alto (C2) y ingreso alto (ABC1). El método de selección de la muestra fue no probabilístico y el tamaño de la muestra (416 sujetos) se determinó por conveniencia, considerando la facilidad de administración, los bajos costos y la disponibilidad de datos demográficos.

\section{Descripción de la encuesta}

La encuesta fue llevada a cabo durante los meses de septiembre y octubre de 2018, en las ciudades más representativas de la región del Maule, Chile, como Talca, Linares y Curicó, con una población total de más de 400.000. La encuesta final se realizó en forma de entrevistas personales en los hogares de las personas. El coeficiente alfa de Cronbach para la encuesta fue 0,812 , lo que indicó que era confiable.

La encuesta consistió en la aplicación de un cuestionario estructurado en cuatro secciones, que incluía preguntas cerradas, de 
Rev. Fac. Agron. (LUZ). 2021, 38(4):1088-1108. Octubre-Diciembre.

\section{Cerda et al.}

third section on conjoint analysis, 8 profiles of lettuce are presented, which are made up of combinations between prices, varieties, and production methods. The individuals were listed from 1 to 8. Additionally, people were asked to rate these profiles from grades 1 to 7 . Finally, a four section on sociodemographic aspects was included.

\section{Conjoint analysis (CA)}

CA uses a decomposition method, in which respondents react to a set of attributes while considering the full product. Each attribute is postulated to be of some importance and provides a stimulus in itself, which helps explain an object's attractiveness or overall level of preference based on these characteristics These preferences are considered consistent with Lancaster's utility maximization theory (Lusk and Hudson, 2004) and can be represented by a global additive utility function, specifically, in our case, with three different prices in Chilean pesos $(\$ 526, \$ 817$ and $\$ 920$ CLP), two lettuce varieties (Lactuca sativa L. var. crispa L. and Lactuca sativa L. var. longifolia (Lam.), and two production systems (organic and non-organic).

The lettuce varieties and price levels were obtained from a preliminary survey which considered one hundred people. The model can be expressed as:

$\mathrm{R}_{\mathrm{k}}(\mathrm{D})=\mathrm{B}_{0}+\sum_{\mathrm{i}=1}^{3} \mathrm{~B}_{1 \mathrm{i}} \mathrm{D}_{1 \mathrm{i}}+\sum_{\mathrm{j}=1}^{2} \mathrm{~B}_{2 \mathrm{j}} \mathrm{D}_{2 \mathrm{j}}+\sum_{\mathrm{i}=1}^{3} \mathrm{~B}_{3 \mathrm{~L}} \mathrm{D}_{3 \mathrm{~L}}$

Where $R_{k}$ represents the dependent variable measured by each of the options that were presented to the study subjects. B represents the utility clasificación, de ordenación y de tipo Likert. La primera sección sobre atributos y preferencias incluyó una escala Likert de uno a cinco, con declaraciones relacionadas con los métodos de producción orgánicos y convencionales de la lechuga, la importancia del precio, el método de producción y las preferencias en cuanto a variedad y tipos.

La segunda sección sobre valoración contingente incluyó un mercado hipotético que se propone a los encuestados, donde se describe el producto orgánico ofrecido y su disponibilidad. Se pregunta directamente a los encuestados si estarían dispuestos a pagar por una unidad de lechuga orgánica y se ofrece un precio aleatorio (oferta) entre los 10 posibles valores estimados.

Según las respuestas de las personas, se hace una segunda pregunta por un precio superior al propuesto o inferior, para aplicar el método dicotómico de doble acotación. En la tercera sección de análisis conjunto, se presentan 8 perfiles de lechuga, los cuales se componen de combinaciones entre precios, variedades y métodos de producción. Los individuos se enumeraron del 1 al 8. Además, se le solicitó a las personas que calificaran estos perfiles del 1 al 7. Finalmente, se incluyó una cuarta sección sobre aspectos sociodemográficos.

\section{Análisis conjunto (CA)}

CA utiliza un método de descomposición, en el que los encuestados reaccionan a un conjunto de atributos mientras consideran el producto completo. Se postula que 
Rev. Fac. Agron. (LUZ). 2021, 38(4):1088-1108. Octubre-Diciembre.

Cerda et al.

of each attribute, where, $i, j, k$ are the attributes, which vary according to their different levels, while $\mathrm{B}_{1 \mathrm{i}}, \mathrm{B}_{2 \mathrm{j}}$, $\mathrm{B}_{31}$ are the coefficients associated with each attribute and measure their partial utility (Ferreira et al., 2009).

Conjoint analysis uses ranking and rating methods. The rating question asks to compare different items using a common scale whereas a ranking question asks to compare different items directly to each other (Ghimire et al., 2016). The value of the marginal WTP for the organic attribute was obtained from:

$\mathrm{WTP}=\frac{\text { coefficient parcial utility organic product }}{\text { price's B WTP }}$

Eight product profiles were obtained through an orthogonal design, generated with the IBM SPPSS Statistics 23 program, thus limiting the number of possible combinations and generating greater efficiency in respondents' responses (Table 1).

\section{Contingent valuation (CV)}

$\mathrm{CV}$ is a hypothetical method that simulates a market throughout a survey, allowing a researcher to obtain the economic value of goods or services that are not necessarily present in the real market. There are different means to determine the willingness to pay (WTP), in this study we used the double-bounded dichotomous choice model. To obtain the payment vector used in the CV method, a preliminary survey of a hundred consumers was conducted to determine the WTP for organic lettuce using an iterative technique to find the minimum mean squared error of the bid design.

The CV model is based on the difference of an indirect utility cada atributo tiene cierta importancia y proporciona un estímulo en sí mismo, que ayuda a explicar el atractivo de un objeto o el nivel general de preferencia basado en estas características. Estas preferencias se consideran consistentes con la teoría de maximización de la utilidad de Lancaster (Lusk y Hudson, 2004) y puede estar representado por una función de utilidad aditiva global, específicamente, en nuestro caso, con tres precios diferentes en pesos chilenos (\$ 526, \$ 817 y \$ 920 CLP), dos variedades de lechuga (Lactuca sativa L.var. crispa L. y Lactuca sativa L. var. . longifolia (Lam.), y dos sistemas de producción (orgánico y no orgánico).

Las variedades de lechuga y los niveles de precios se obtuvieron de una encuesta preliminar que consideró a cien personas. El modelo se puede expresar como:

$\mathrm{R}_{\mathrm{K}}(\mathrm{D})=\mathrm{B}_{0}+\sum_{\mathrm{i}=1}^{3} \mathrm{~B}_{1 \mathrm{i}} \mathrm{D}_{1 \mathrm{i}}+\sum_{\mathrm{i}=1}^{2} \mathrm{~B}_{2 \mathrm{j}} \mathrm{D}_{2 \mathrm{j}}+\sum_{\mathrm{k}=1}^{3} \mathrm{~B}_{3 \mathrm{~L}} \mathrm{D}_{3 \mathrm{~L}}$

Donde $R_{K}$ representa la variable dependiente, medida por cada una de las opciones que se presentaron a los sujetos de estudio. B representa la utilidad de cada atributo, donde $\mathrm{i}, \mathrm{j}, \mathrm{k}$ son los atributos, que varían según sus diferentes niveles, mientras $B_{1 i}, \quad B_{2 j}, B_{31}$ que son los coeficientes asociados a cada atributo y miden su utilidad parcial. (Ferreira et al., 2009).

El análisis conjunto utiliza métodos de ordenamiento y calificación. La pregunta de valoración pide comparar diferentes elementos utilizando una escala común, mientras que una pregunta de ordenamiento solicita 
Rev. Fac. Agron. (LUZ). 2021, 38(4):1088-1108. Octubre-Diciembre.

\section{Cerda et al.}

ISSN 2477-9407

function, i.e., a random variable with some probability distribution used for the parameters. The linear expression for the difference in the indirect utility function model is $\Delta v \mathrm{i}=\alpha+B \mathrm{~A}_{\mathrm{i}}+\eta$, where $A_{i}$ is the payment vector to which individuals respond if they are willing comparar diferentes elementos directamente entre sí (Ghimire et al., 2016). El valor de la WTP marginal para el atributo orgánico se obtuvo de:

$\mathrm{WTP}=\frac{\text { coeficiente de utilidad parcial producto orgánico }}{\text { precio B WTP }}$

\section{Tabla 1. Orthogonal design for lettuce profiles.}

Cuadro 1. Diseño ortogonal para perfiles de lechuga.

\begin{tabular}{cccc}
\hline Profile & System of Production & Lettuce Variety & Lettuce Price (\$) \\
\hline 1 & Conventional & Lactuca sativa L. var. longifolia (Lam.) & 920 \\
2 & Conventional & Lactuca sativa L. var. crispa L. & 817 \\
3 & Organic & Lactuca sativa L. var. longifolia (Lam.) & 817 \\
4 & Organic & Lactuca sativa L. var. longifolia (Lam.) & 920 \\
5 & Organic & Lactuca sativa L. var. crispa L. & 920 \\
6 & Conventional & Lactuca sativa L. var. crispa L. & 920 \\
7 & Organic & Lactuca sativa L. var. crispa L. & 526 \\
8 & Conventional & Lactuca sativa L. var. longifolia (Lam.) & 526 \\
\hline
\end{tabular}

${ }^{1} \mathrm{CLP}=$ Chilean pesos.

${ }^{1} \mathrm{CLP}=$ Pesos chilenos.

to pay for ahead of organic lettuce and is the error estimate that is $\eta$ assumed to have a logistic distribution.

To measure the maximum WTP for the product, a hypothetical market was created, where the value that an individual assigns to the extracted lettuce is related to its organic nature. The average WTP for an indirect utility function corresponds to:

\section{$\mathrm{E}(\mathrm{WTP})=-\alpha / B$}

To apply the above, the first step was to obtain payment vectors in which the product and its benefits were described, then the product quantity, payment method, and product provision, among other aspects, were considered, all of
Se obtuvieron ocho perfiles de producto mediante un diseño ortogonal, generado con el programa IBM SPPSS Statistics 23, limitando así el número de combinaciones posibles y generando mayor eficiencia en las respuestas de los encuestados (Cuadro 1).

\section{Evaluación contingente (CV)}

La CV es un método hipotético que simula un mercado por medio de una encuesta, permitiendo al investigador obtener el valor económico de bienes o servicios que no necesariamente están presentes en el mercado real. Existen diferentes medios para determinar la disposicion a pagar (WTP), en este estudio utilizamos el modelo de elección dicotómica de doble 
Rev. Fac. Agron. (LUZ). 2021, 38(4):1088-1108. Octubre-Diciembre.

which attempt to simulate a real market (Table 2). límite. Para obtener el vector de pago utilizado en el método $\mathrm{CV}$, se realizó

\section{Table 2. Optimal bid vector of WTP for organic lettuce, sample size and bid frequency.}

Cuadro 2. Vector de oferta óptimo de WTP para lechuga orgánica, tamaño de muestra y frecuencia de oferta.

\begin{tabular}{cccccccc}
\hline Initial bid $^{1}$ & Upper bid $^{1}$ & Lower bid $^{1}$ & Sample distribution & \multicolumn{4}{c}{ Response for each bid (\%) } \\
\hline & & & $\mathrm{n}=416$ & Yes-Yes & Yes-No & No-Yes & No-No \\
\hline 422 & 497 & 211 & 30 & 83 & 13 & 3 & 0 \\
572 & 625 & 497 & 50 & 82 & 10 & 2 & 6 \\
678 & 723 & 625 & 42 & 57 & 31 & 2 & 10 \\
767 & 808 & 723 & 45 & 60 & 18 & 0 & 22 \\
849 & 889 & 808 & 43 & 74 & 5 & 21 & 0 \\
929 & 970 & 889 & 45 & 51 & 11 & 4 & 33 \\
1011 & 1056 & 970 & 43 & 51 & 5 & 23 & 21 \\
1100 & 1153 & 1056 & 49 & 39 & 8 & 4 & 49 \\
1206 & 1281 & 1153 & 46 & 43 & 2 & 0 & 54 \\
1356 & 1500 & 1281 & 23 & 13 & 13 & 0 & 74 \\
\hline
\end{tabular}

${ }^{1} \mathrm{CLP}=$ Chilean peso. Exchange rate: 1 USD $=653$ CLP, June 30, 2018.

${ }^{1}$ CLP $=$ Pesos chilenos. Tasa de cambio: 1 USD = 653 CLP, Junio 30, 2018.

\section{Results and discussion}

\section{Sample descriptive analysis}

Regarding the descriptive analysis of the sample, 416 surveys were classified by socioeconomic level. Sociodemographic definitions are listed in Table 3. Of the total number of respondents, $58.9 \%$ were women, and of these, $65.9 \%$ were between $26-60$ years old, belonged to the medium-low and medium-high income strata, and $88 \%$ of them had high school or undergraduate education (Table 3).

Additionally, $98.6 \%$ of the respondents had a good or very good knowledge of organic products in general and there was a favorable behavior una encuesta preliminar a un centenar de consumidores para determinar la WTP de lechuga orgánica mediante una técnica iterativa para encontrar el error cuadrático medio mínimo del diseño de oferta.

El modelo de CV se basa en la diferencia de una función de utilidad indirecta, es decir, una variable aleatoria con alguna distribución de probabilidad utilizada para los parámetros. La expresión lineal para la diferencia en el modelo de función de utilidad indirecta es $\Delta v \mathrm{i}=\alpha+B \mathrm{~A}_{\mathrm{i}}+\eta$ donde $A_{i}$ es el vector de pago al que responden los individuos si están dispuestos a pagar antes que la lechuga orgánica y $\eta$ es la estimación 
Rev. Fac. Agron. (LUZ). 2021, 38(4):1088-1108. Octubre-Diciembre.

Cerda et al.

ISSN 2477-9407

towards them, as $90.1 \%$ stated that they have consumed this type of product at least once, leaving only $9.9 \%$ who never have done so. No significant differences were found regarding the gender. The main reason for consumption, $53.07 \%$ of the sample said that they consume these products to find better quality in them, $15.2 \%$ said they do so because they like the taste or smell of these products, and $14.4 \%$ due to the belief that organic foods have a higher nutritional content than conventional products, among other reasons. del error que se supone que tiene una distribución logística.

Para medir la WTP máxima del producto, se creó un mercado hipotético, donde el valor que un individuo asigna a la lechuga extraída está relacionado con su naturaleza orgánica. La DAP media para una función de utilidad indirecta corresponde a:

$\mathrm{E}(\mathrm{WTP})=-\alpha / 6$.

Para aplicar lo anterior, el primer paso fue obtener vectores de pago en los que se describiera el producto y sus beneficios, luego se consideró la

\section{Table 3. Sample description.}

Cuadro 3. Descripción de la muestra.

\begin{tabular}{ccc}
\hline Item & & Percent \\
\hline Gender & Female & 58.9 \\
& Male & 41.1 \\
& $18-25$ & 21.4 \\
Age & $26-35$ & 20.9 \\
& $36-45$ & 16.6 \\
& $46-60$ & 28.4 \\
& $60+$ & 12.7 \\
Sociodemographic ${ }^{1}$ & High Income & 12.5 \\
& Medium-High Income & 35.6 \\
High School & Medium-Low Income & 50.5 \\
Undergraduate & 47.1 & 8.4 \\
Graduate & 40.9 & \\
\hline
\end{tabular}

${ }^{1}$ Approximation to Chilean income stratification.

${ }^{1}$ Aproximación a la estratificación por ingresos de Chile

\section{Conjoint analysis results}

The results show that, concerning the lettuce production system, the organic method obtained the highest utility score. The consumption of organic products showed a positive value reflecting consumers' favorable attitude towards cantidad del producto, la forma de pago y la provisión del producto, entre otros aspectos, todo lo cual intenta simular un mercado real (Cuadro 2).

Cuadro 2. Vector de oferta óptimo de WTP para lechuga orgánica, tamaño de muestra y frecuencia de oferta. 
Rev. Fac. Agron. (LUZ). 2021, 38(4):1088-1108. Octubre-Diciembre.

Cerda et al.

ISSN 2477-9407

them (Table 4). Otherwise, the variety characteristic follows, Lactuca sativa L. var. longifolia (Lam) and Lactuca sativa L. var. crispa $\mathrm{L}$. The partial utility provided by the lettuce variety variable was lower than that used in the production system. Finally, the price had a negative linear relationship to utility, which is consistent with the theory, as consumers prefer lower prices on the selected products. The price CLP 526 (USD 0.81) delivered the highest partial utility in both cases. Both statistics showed a high correlation between the observed data and the proposed model.

\section{Resultados y discusión}

\section{Análisis descriptivo de la muestra}

En cuanto al análisis descriptivo de la muestra, se clasificaron 416 encuestas por nivel socioeconómico. Las definiciones sociodemográficas se enumeran en la Cuadro 3. Del total de encuestados, el 58,9 \% eran mujeres, y de estas, el 65,9\% tenían entre 26 y 60 años, pertenecían a los estratos de ingresos medio-bajo y medio-alto, y el 88\% de ellos tenían estudios secundarios o universitarios (Cuadro 3).

Table 4. CA estimations of utility for ranking and rating (score) method.

Tabla 4. Estimaciones por CA de la utilidad para el método de ordenamiento y calificación (puntuación).

\begin{tabular}{|c|c|c|c|}
\hline & & $\begin{array}{l}\text { Ranking Model Utility } \\
\text { Estimation }\end{array}$ & $\begin{array}{c}\text { Rating Model Utility } \\
\text { Estimation }\end{array}$ \\
\hline \multirow{2}{*}{ Productionsystem } & Conventional & $\begin{array}{l}-0.964 \\
(0.148)\end{array}$ & $\begin{array}{l}-0.508 \\
(0.063)\end{array}$ \\
\hline & Organic & $\begin{array}{c}0.964 \\
(0.148)\end{array}$ & $\begin{array}{c}0.508 \\
(0.063)\end{array}$ \\
\hline \multirow{2}{*}{ Variety } & $\begin{array}{l}\text { Lactuca sativa } \mathrm{L} \text {. } \\
\text { var. crispa } \mathrm{L} \text {. }\end{array}$ & $\begin{array}{l}-0.155 \\
(0.148)\end{array}$ & $\begin{array}{l}-0.059 \\
(0.063)\end{array}$ \\
\hline & $\begin{array}{c}\text { Lactuca sativa } \mathrm{L} . \\
\text { var. longifolia (Lam.) }\end{array}$ & $\begin{array}{c}0.155 \\
(0.148)\end{array}$ & $\begin{array}{c}0.059 \\
(0.063)\end{array}$ \\
\hline \multirow{3}{*}{ Price } & CLP 526/USD 0.81 & $\begin{array}{l}-2.826 \\
(0.482)\end{array}$ & $\begin{array}{l}-1.235 \\
(0.205)\end{array}$ \\
\hline & CLP 817/USD 1.25 & $\begin{array}{l}-4.390 \\
(0.749)\end{array}$ & $\begin{array}{l}-1.919 \\
(0.318)\end{array}$ \\
\hline & CLP 920/USD 1.41 & $\begin{array}{l}-4.944 \\
(0.843)\end{array}$ & $\begin{array}{l}-2.161 \\
(0.359)\end{array}$ \\
\hline \multicolumn{2}{|c|}{ (Constant) } & $\begin{array}{c}8.764 \\
(0.744)\end{array}$ & 6.978 \\
\hline \multicolumn{2}{|c|}{ Pearson's R } & 0.975 & 0.973 \\
\hline \multicolumn{2}{|c|}{ Price $B$} & $-0,005373$ & -0.002349 \\
\hline \multicolumn{2}{|c|}{ MWTP } & $\begin{array}{l}\$ 179.42^{1} \\
\left(\$ 0.28^{2}\right)\end{array}$ & $\begin{array}{l}\$ 216.26^{1} \\
\left(\$ 0.33^{2}\right)\end{array}$ \\
\hline
\end{tabular}

In parentheses: standard error; ${ }^{1} \mathrm{CLP}=$ Chilean peso. ${ }^{2} \mathrm{USD}=\mathrm{USA}$ dolar.

Entre paréntesis: error estándar; ${ }^{1} \mathrm{CLP}=$ Peso chileno. ${ }^{2} \mathrm{USD}=$ Dólar estadounidense 
Rev. Fac. Agron. (LUZ). 2021, 38(4):1088-1108. Octubre-Diciembre.

Cerda et al.

ISSN 2477-9407

When evaluating the relative importance of the attributes, importance score averages were obtained. Here, the price was relatively dominant, followed by the production method, and finally the variety. To estimate the marginal willingness to pay (MWTP), a linear relationship was estimated between the three prices and the estimated coefficients for each of them.

The slope of this estimate allowed us to find a single price coefficient for each case, ranking, and rating (-0.0053 and -0.0023), which was used to estimate the MWTP $(0.964 / 0.005373=179.42$ and $\quad 0.508 / 0.002349=216.26$ ). Therefore, the WTP determined by the ranking method, that is, the premium paid above to obtain an organic lettuce was CLP 179.46 (USD $0.28)$. This represented $26.73 \%$ of the average market price of conventional lettuce. In terms of rating (score), the marginal WTP for such organic products was CLP 216.26 (USD 0.33), which represented $32.21 \%$ of the average market price.

\section{Contingent valuation results}

The results of the double-bounded dichotomous choice model are presented in Table 5. The WTP obtained by the CV method reached CLP 1,027 per head of organic lettuce. The confidence intervals were generated with $99 \%$ confidence and the expected WTP fell between CLP 967 (USD 1.48) and CLP 1,094 (USD 1.68). The price coefficient was negative, which is consistent with the theory, showing that consumers' WTP decreases as item price increases (Cerda et al., 2010). Both coefficients were significant at the $99 \%$ confidence level.
Adicionalmente, el $98,6 \%$ de los encuestados tenía un conocimiento bueno o muy bueno de los productos orgánicos en general y hubo un comportamiento favorable hacia ellos, ya que el 90,1\% afirmó haber consumido este tipo de producto al menos una vez, quedando solo el $9,9 \%$ que nunca lo han hecho. No se encontraron diferencias significativas en cuanto al género. El principal motivo de consumo, el 53,07\% de la muestra dijo que consume estos productos para encontrar mejor calidad en ellos, el $15,2 \%$ dijo que lo hace porque les gusta el sabor u olor de estos productos, y el $14,4 \%$ por la creencia de que lo orgánico los alimentos tienen un mayor contenido nutricional que los productos convencionales, entre otras razones.

\section{Resultados del análisis conjunto (CA)}

Los resultados muestran que, en cuanto al sistema de producción de lechuga, el método orgánico obtuvo el puntaje de utilidad más alto. El consumo de productos orgánicos mostró un valor positivo reflejando la actitud favorable de los consumidores hacia ellos (Cuadro 4). En caso contrario, sigue la característica de la variedad, Lactuca sativa L. var. longifolia (Lam) y Lactuca sativa L. var. crispa L. La utilidad parcial proporcionada por la variable variedad de lechuga fue menor que la utilizada en el sistema de producción. Finalmente, el precio tuvo una relación lineal negativa con la utilidad, lo cual es consistente con la teoría, ya que los consumidores prefieren precios más bajos en los productos seleccionados. 
Rev. Fac. Agron. (LUZ). 2021, 38(4):1088-1108. Octubre-Diciembre.

Cerda et al.

Table 5. CV model results.

Tabla 5. Resultados del modelo de CV.

\begin{tabular}{ccc}
\hline Variable & Traditional Model & Expanded Model \\
\hline Constant & 4,7015 & $3.65692^{1}$ \\
& $(0.4294)$ & $(0.5688)$ \\
Bid & $-0.00457^{1}$ & $-0.00460^{1}$ \\
& $(0.0004)$ & $(0.0004)$ \\
Income & - & $0.42206^{1}$ \\
& & $(0.1582)$ \\
Log-likelihood & -431 & -428 \\
\hline 99 \% Confidence & 967.2 to $1,094.4^{1}$ & 972.8 to $1,103.9^{1}$ \\
interval & &
\end{tabular}

Standard error in parenthesis. $1 \mathrm{CLP}=$ Chilean pesos

Coefficients are significant at $\mathrm{p}<0.05$. ${ }^{1} \mathrm{p}$-value is $<0.00001$.

Error estándar entre paréntesis. ${ }^{1} \mathrm{CLP}=$ Pesos chilenos

Los coeficientes son significativos a $p<0,05 .{ }^{1}$ valor de $\mathrm{p}$ es $<0,00001$.

This study shows that there is a positive WTP for organic products. The premium price is equal to CLP 355 (USD 0.54), that is, $52.83 \%$ higher than the market price for conventionally grown lettuce heads. This could indicate that people care about sustainable development, the environment, and health care, all factors that are considered when buying organic lettuce when it is visible and available in the market.

As mentioned above, there is almost no research on WTP for organic lettuce. The closest research is a study for consumers in México (HernandezOrtiz et al., 2019), where the authors estimated the WTP for various organic products, including lettuce, for which a value of $7.5 \mathrm{MXN}$, equivalent to 0.30 USD, was found, similar to that found in our study. Omotesho et al. (2016) examined the WTP for lettuce in supermarkets and specialty stores
El precio CLP 526 (USD 0,81) entregó la utilidad parcial más alta en ambos casos. Ambas estadísticas mostraron una alta correlación entre los datos observados y el modelo propuesto.

Alevaluar laimportanciarelativa de los atributos, se obtuvieron promedios de puntuación de importancia. Aquí, el precio fue relativamente dominante, seguido por el método de producción y finalmente la variedad. Para estimar la disposición marginal a pagar (MWTP), se estimó una relación lineal entre los tres precios y los coeficientes estimados para cada uno de ellos.

La pendiente de esta estimación nos permitió encontrar un coeficiente de precio único para cada caso, ordenamiento y calificación $(-0,0053$ y -0,0023), que se utilizó para estimar el MWTP $(0,964 / 0,005373=179,42 \mathrm{y}$ $0,508 / 0,002349=216,26)$. Por lo tanto, la WTP determinada por el método de ordenamiento, es decir, la prima 
Rev. Fac. Agron. (LUZ). 2021, 38(4):1088-1108. Octubre-Diciembre.

\section{Cerda et al.}

in Nigeria, but the value was lower than the regular market price of nonorganic lettuce.

Our WTP results exceeded those found for other products, especially fruits. Cerda et al., (2012) and Cerda et al., (2015) reported that consumers were willing to pay a premium of 30 $\%$ for organic apples and $26.67 \%$ for organic pears. However, our results are similar to those obtained by Cerda et al., (2011) where the WTP reached $51.63 \%$ above the price of conventional table grapes.

Using the $\mathrm{CV}$ approach, an average WTP was found that exceeded $53.12 \%$ of the average market price. To obtain expanded results, the income variable was incorporated in the model, which showed that the income coefficient has a direct linear relationship with the dependent variable. In other words, if income increases, individuals are more willing to buy the good (income elasticity of the demand is positive).

\section{Comparison between models}

The amount to be paid obtained by the models used in this study was estimated as a percentage of the price premiums based on the current average market price of lettuce, which was estimated by looking at prices paid in farmer's markets and supermarkets, places where Chileans frequently buy food. The premium WTP, for the traditional and expanded CV models, were $52,83 \%$ and $53,57 \%$, respectively. In the case of $\mathrm{CA}$, the premium WTP for ranking and rating models were $21,9 \%$ and $26,4 \%$, respectively.

As mentioned in the literature, the premium WTP tends to be greater pagada por encima para obtener una lechuga orgánica fue de CLP 179,46 (USD 0,28). Esto representó el 26,73 $\%$ del precio medio de mercado de la lechuga convencional. En términos de valoración (puntaje), la WTP marginal de dichos productos orgánicos fue de CLP 216,26 (USD 0,33), lo que representó el $32,21 \%$ del precio medio de mercado.

Resultados de la valoración contingente (CV).

Los resultados del modelo de elección dicotómica de doble acotación se presentan en la Cuadro 5. La WTP obtenida por el método CV alcanzó CLP 1.027 por cabeza de lechuga orgánica. Los intervalos de confianza se generaron con $99 \%$ de confianza y la WTP esperada cayó entre CLP 967 (USD 1,48) y CLP 1.094 (USD 1,68). El coeficiente de precio fue negativo, lo que es consistente con la teoría, que muestra que la WTP de los consumidores disminuye a medida que aumenta el precio del artículo (Cerda et al., 2010). Ambos coeficientes fueron significativos al nivel de confianza del $99 \%$.

Este estudio muestra que existe una WTP positiva para los productos orgánicos. El precio de la prima es igual a CLP 355 (USD 0,54), es decir, un $52,83 \%$ más alto que el precio de mercado de las cabezas de lechuga cultivadas de forma convencional. Esto podría indicar que las personas se preocupan por el desarrollo sostenible, el medio ambiente y el cuidado de la salud, todos factores que se consideran al comprar lechuga orgánica cuando está visible $\mathrm{y}$ disponible en el mercado. 
Rev. Fac. Agron. (LUZ). 2021, 38(4):1088-1108. Octubre-Diciembre.

with the CV method than with the CA approach, which is consistent with our results, because the percentage difference between $\mathrm{CV}$ and $\mathrm{CA}$ is considerably high. However, our results of ranking and rating estimates provided very similar values in the $\mathrm{CA}$ approach, which is consistent with the results mentioned by Hino and Imai (2018).

The differences between a CV and CA can be mainly due to four reasons: first, due to the considerations made by the individuals when they answered the survey, regarding the existence or not of substitute products, which may be more explicit in the CA approach. Second, the psychological aspects involved in the process of choosing goods or services; for the CA approach, individuals chose alternative products with different attributes (including price), whereas in CV they assigned a monetary value.

The third reason is the possibility of ambivalence responses, as can happen with CA. Finally, the uncertainty faced by the individuals, is associated with each of the choices they made (Stevensa et al., 2000). It worth pointed out that the results of both methods indicate that consumers value the production of organic lettuce. This is an argument in favor of the cultivation of organic products and the respective certification as a signal to consumers.

\section{Conclusions}

The utilities estimated through the CA method for each attribute indicates that the variety Lactuca sativa L.
Como se mencionó anteriormente, casi no hay investigaciones sobre la WTP para la lechuga orgánica. La investigación más cercana es un estudio para consumidores en México (Hernandez-Ortiz et al., 2019), donde los autores estimaron la DAP de varios productos orgánicos, incluida la lechuga, para lo cual se encontró un valor de 7,5 MXN, equivalente a 0,30 USD, similar al encontrado en nuestro estudio. Omotesho et al., (2016) examinaron la DAP de la lechuga en los supermercados y tiendas especializadas en Nigeria, pero el valor era más bajo que el precio normal de mercado de la lechuga no orgánica.

Nuestros resultados de WTP superaron los encontrados para otros productos, especialmente frutas. Cerda et al., (2012) y Cerda et al., (2015) informaron que los consumidores estaban dispuestos a pagar una prima del $30 \%$ por las manzanas orgánicas y del 26,67 $\%$ por las peras orgánicas. Sin embargo, nuestros resultados son similares a los obtenidos por Cerda et al., (2011) donde la DAP alcanzó un 51,63\% por encima del precio de la uva de mesa convencional.

Utilizando el enfoque de CV, se encontró una WTP media que excedía el 53,12\% del precio medio de mercado. Para obtener resultados expandidos, se incorporó al modelo la variable ingreso, que mostró que el coeficiente de ingreso tiene una relación lineal directa con la variable dependiente. En otras palabras, si el ingreso aumenta, los individuos están más 
Rev. Fac. Agron. (LUZ). 2021, 38(4):1088-1108. Octubre-Diciembre.

\section{Cerda et al.}

var. crispa., produced organically and at the lowest observed price, is the most preferred by consumers. Additionally, it is important to mention that consumers have a WTP for organic lettuces, even paying a 50 $\%$ premium on top of what they would pay for conventional lettuce.

Organic products are most appreciated by a specific group of consumers, mainly those with higher incomes that have a greater probability to pay a premium price for organic lettuces. Therefore, organic lettuce producers and marketers should focus their promotion strategies mainly on high socioeconomic segments and sales in higher income countries. Additionally, no significant differences were found regarding the gender, this means that lettuce producers would not need a gender-differentiated promotion strategy.

Finally, the main reasons to consume this type of product are, firstly, its higher quality, followed by its particular taste or smell, and finally, it has better nutritional contents. Therefore, lettuce growers can use the estimated premium price as a reference when making decisions about production and pricing.

\section{End of English Version}

dispuestos a comprar el bien (la elasticidad ingreso de la demanda es positiva).

\section{Comparación entre modelos}

El monto a pagar obtenido por los modelos utilizados en este estudio se estimó como un porcentaje de los sobreprecios con base en el precio promedio de mercado actual de la lechuga, el cual se estimó observando los precios pagados en los mercados de agricultores y supermercados, lugares donde los chilenos con frecuencia compran comida. La WTP premium, para los modelos $\mathrm{CV}$ tradicional y expandido, fue de $52,83 \%$ y $53,57 \%$, respectivamente. En el caso de CA, la WTP premium para los modelos de ordenamiento y calificación fue de $21,9 \%$ y $26,4 \%$, respectivamente.

Como se menciona en la literatura, la WTP premium tiende a ser mayor con el método $\mathrm{CV}$ que con el enfoque $\mathrm{CA}$, lo cual es consistente con nuestros resultados, porque la diferencia porcentual entre $\mathrm{CV} y$ CA es considerablemente alta. Sin embargo, nuestros resultados de las estimaciones de ordenamiento y calificación proporcionaron valores muy similares en el enfoque de CA, lo cual es consistente con los resultados mencionados por Hino e Imai (2018).

Las diferencias entre CV y AC pueden deberse principalmente a cuatro motivos: primero, a las consideraciones que hicieron los individuos al contestar la encuesta, sobre la existencia o no de productos sustitutos, que pueden ser más explícitos en el enfoque de AC. En segundo lugar, los aspectos psicológicos involucrados en el proceso de elección de bienes o servicios; para el enfoque $\mathrm{CA}$, los individuos eligieron productos alternativos con diferentes atributos (incluido el precio), mientras que en $\mathrm{CV}$ asignaron un valor monetario.

La tercera razón es la posibilidad de respuestas de ambivalencia, tal como 
Rev. Fac. Agron. (LUZ). 2021, 38(4):1088-1108. Octubre-Diciembre.

puede suceder con la AC. Finalmente, la incertidumbre que enfrentan los individuos, está asociada a cada una de las elecciones que hicieron (Stevensa et al., 2000). Cabe señalar que los resultados de ambos métodos indican que los consumidores valoran la producción de lechuga orgánica. Este es un argumento a favor del cultivo de productos orgánicos y a la respectiva certificación como indicación para los consumidores.

\section{Conclusiones}

Las utilidades estimadas mediante el método $\mathrm{CA}$ para cada atributo indican que la variedad Lactuca sativa L. var. crispa, producida orgánicamente y al precio más bajo observado, es la más preferida por los consumidores. Además, es importante mencionar que los consumidores tienen una WTP para lechugas orgánicas, incluso pagando un $50 \%$ más de lo que pagarían por la lechuga convencional.

Los productos orgánicos son más apreciados por un grupo específico de consumidores, principalmente aquellos con mayores ingresos que tienen una mayor probabilidad de pagar un precio superior por las lechugas orgánicas. Por lo tanto, los productores y comercializadores de lechuga orgánica deben enfocar sus estrategias de promoción principalmente en los segmentos socioeconómicos altos y las ventas en los países de ingresos más altos. Adicionalmente, no se encontraron diferencias significativas en cuanto al género, esto significa que los productores de lechuga no necesitarían una estrategia de promoción diferenciada por género.

Finalmente, las principales razones para consumer este tipo de productos son, en primer lugar, su mayor calidad, seguido de su sabor $\mathrm{u}$ olor particular, y por ultimo, su mejor contenido nutricional. Por lo tanto, los productores de lechuga pueden usar el precio de la prima estimada como referencia al tomar decisiones sobre producción y precios.

\section{Cited literature}

Ahmed, J., T. Tefera and G.T. Kassie. 2020. Consumers' preference and willingness to pay for enriched snack product traits in Shashamane and Hawassa cities, Ethiopia. Agricultural and Food Economics, 8(14):1-20. https://doi.org/10.1186/ s40100-020-00157-1

Bhattarai, K. 2019. Consumers'Willingness to Pay for Organic Vegetables: Empirical Evidence from Nepal. Journal of Scientific Papers, Economics \& Sociology 12(3): 132146. https://doi.org/10.14254/2071789X.2019/12-3/9

Britwum, K. and A. Yiannaka. 2019. Labeling food safety attributes: to inform or not to inform?. Agricultural and Food Economics, 7(4):1-21. https://doi.org/10.1186/ s40100-019-0123-y

Cerda, A., L. García, J. Cancino and A. Nunez. 2011. Preferences and wiligness to pay for table grapes in the region of Maule, Chile. Revista Brasileira de Fruticultura, 33(3): 784-790. https://doi.org/10.1590/ S0100-29452011000300012

Cerda, A., L. Garcia, S. Ortega-Farias and A. Ubilla. 2012. Consumer preferences and willingness to pay for organic apples. Ciencia $e$ Investigación Agraria, 39(1): 4759. https://doi.org/10.4067/S071816202012000100004 
Rev. Fac. Agron. (LUZ). 2021, 38(4):1088-1108. Octubre-Diciembre.

Cerda et al.

ISSN 2477-9407

Cerda, A., L. García, F. Tolosa and V. García. 2015. Preferences and willingness to pay for organic pears among highincome people in the Metropolitan Region of Santiago, Chile. Ciencia e Investigación Agraria, 42(2): 181189. https://doi.org/10.4067/S071816202015000200005

Cerda, A.A., L.Y. García, F. Tolosa and V. García. 2014. Preferencias y disposición a pagar por manzanas orgánicas en la Región Metropolitana de Santiago de Chile. Revista de la Facultad de Agronomía (LUZ), 31(2): 274-289. https://cutt.ly/xQydLeu

Cerda, A., García, L., Bahamondez, A., \& Poblete, V. (2010). Comparison of Willingness To Pay (WTP) for an Improvement in Air Quality between Users and Nonusers of Firewood in the City of Talca (Chile). Lecturas de Economía, (72), 195-211. EID: 2-s2.084875569915 http://www.scopus. com/inward/record.url?eid=2-s2.0875569915\&partnerID=MN8TOARS

Food and Agriculture Organization (FAO). 2020. Production quantities of Lettuce and chicory by country. Available on: https://cutt.ly/yQyhRG5 Date of consultation: January 2021.

Ferreira, S.D., A. Rial, E. Picón and J. Varela. 2009. Efecto del orden de presentación de los atributos sobre los resultados del Análisis Conjunto. Metodología de Encuestas. 11:103-119. https://cutt.ly/ AQyfeZy

Ghimire, M., T.A. Boyer, C.J. Chung and J.Q. Moss. 2016. Consumers' Shares of Preferences for Turfgrass Attributes Using a Discrete Choice Experiment and the Best-Worst Method. Hortscience. 51(7):892-898. https:// doi.org/10.21273/HORTSCI.51.7.892

Hernandez-Ortiz, J., J. Trujillo-Murillo and M. Martinez-Damian. 2019. Disposición a pagar por productos orgánicos en Texcoco, Estado de México. Revista Mexicana de Ciencias Agrícolas, 10(7): 1685-1691. https:// doi.org/10.29312/remexca.v10i7.926

Hino, A. and R. Imai. 2018. Ranking and Rating: Neglected Biases in Factor Analysis of Postmaterialist Values. International Journal of Public
Opinion Research, 31(2):368-381. https://doi.org/10.1093/ijpor/edy007

Jouzi, Z., H. Azadi, F. Taheri, K. Zarafshani, K. Gebrehiwot, S. Van Passel and P. Lebailly. 2017. Organic farming and small-scale farmers: Main opportunities and challenges. Ecological Economics. 132(1):144154. https://doi.org/10.1016/j. ecolecon.2016.10.016

Kushwah, S., A. Dhir, M. Sagar and B. Gupta. 2019. Determinants of organic food consumption. A systematic literature review on motives and barriers. Appetite. 143(1):104402. https://doi. org/10.1016/j.appet.2019.104402

Li, R., H.-Y. Lee, Y.-T. Lin, C.-W. Liu and P.F. Tsai. 2019. Consumers' willingness to pay for organic foods in China: Bibliometric review for an emerging literature. $\square$ International Journal of Environmental Research and Public Health, 16(10):1713. https://doi. org/10.3390/ijerph16101713

Lusk, J.L. and D. Hudson. 2004. Willingness-to-pay estimates and their relevance to agribusiness decision making. Review of Agricultural Economics, 26(2):152169. https://doi.org/10.1111/j.14679353.2004.00168.x

Nishi, I.F., 2017. Consumer willingness to pay for local vegetables grown in a controlled environment: the case of lettuce. Applied Economics and Management. Cornell University, Cornell University Library. p.54. Available on: https://doi.org/10.7298/ X4X63K37 Date of consultation: July 122021.

Omotesho, O.A., A. Falola, K.F. Omotesho and A.S. Abikoye. 2016. Consumers' Willingness to Pay for Lettuce in Supermarkets and Specialty Shops in Ilorin Metropolis, Nigeria Centrepoint Journal (Science Edition). 22(1): 3649. https://cutt.ly/qQygqTA

Pham, T.H., T.N. Nguyen, T.T.H. Phan and N.T. Nguyen. 2019. Evaluating the purchase behaviour of organic food by young consumers in an emerging market economy. Journal of Strategic Marketing, 27(6): 540-556. https://doi. org/10.1080/0965254X.2018.1447984 
Rev. Fac. Agron. (LUZ). 2021, 38(4):1088-1108. Octubre-Diciembre.

Cerda et al.

ISSN 2477-9407

Rahman, S., M. Mele, Y. Lee and M. Islam. 2021. Consumer Preference, Quality, and Safety of Organic and Conventional Fresh Fruits, Vegetables, and Cereals. Foods. 10(1):105. https://doi.org/10.3390/ foods 10010105

Ranjbarshamsi, H., M. Najafabadi and S. Hosseini. 2016. Factors Influencing Consumers'Attitudes Toward Organic Agricultural Products. Journal of Agricultural \& Food Information 17(2): 110-119. https://doi.org/10.108 0/10496505.2016.1176574

Shatilov, M., Razin, A. and Ivanova, M. 2019. Analysis of the world lettuce market. IOP Conference Series: Earth and Environmental Science. 395(1):12053. https://doi.org/10.1088/1755. 1315/395/1/012053

Schleenbecker, R. and Hamm, U. (2013). Consumers' perception of organic product characteristics. A review. Appetite. 71(1):420-429. https://doi. org/10.1016/j.appet.2013.08.020
Stevensa, T. H., Belknera, R., Dennisc, D., Kittredgeb, D. and Willisa, C. 2000. Comparison of contingent valuation and conjoint analysis in ecosystem management. $\square$ Ecological Economics, 32(1): 63-74. https://doi. org/10.1016/S0921-8009(99)00071-3

Wang, Y., Zhu, Z. and Chu, F. 2017. Organic vs. Non-Organic Food Products: Credence and Price Competition. Sustainability. 9(4):545. https://doi. org/10.3390/su9040545

Willer, H., Schlatter, B., Travinicek, J., Kemper, L. and Lernoud, J. E. (2020). The World of Organic Agriculture - Statistics \& Emerging Trends 2020. Research Institute of Organic Agrigulture (FiBL). Frick, Switzerland, p.337. https://cutt.ly/ dQyhsCB 